\section{Field test for bright
to go ahead soon \\ Washington}

THE US Environmental Protection Agency (EPA) last week approved the first field test of a recombinant organism to fall under the Toxic Substances Control Act (TSCA). A unanimous vote by EPA's biotechnology advisory committee has cleared the way for Monsanto to field test a strain of fluorescent Pseudomonas aureofaciens containing lac $Z Y$ marker genes that will allow the strain to be tracked in the environment. Monsanto plans to introduce genes for agriculturally beneficial proteins into the strain, and the marker genes will be used to assess the movement of the engineered bacteria.

TSCA is one of two regulatory statutes that EPA uses to control the release of recombinant organisms into the environment, under the Coordinated Framework for Biotechnology announced in June of 1986. It was originally developed for overseeing chemical substances, and requires a company or individual to notify EPA 90 days before making a new chemical not on EPA's master list of approved compounds. EPA normally conducts riskbenefit analysis to determine if the substance should be regulated, but if EPA fails to respond within the 90-day approval period, the company has tacit approval to make, use and sell the substance, causing concern that some notifications might slip through the regulatory net.

Most recombinant organisms are expected to be regulated under TSCA, but the first environmental release of a genetically altered bacteria - a Pseudomonas with a deletion for ice-nucleation, developed by Advanced Genetic Sciences - was permitted under the Federal Insecticide, Fungicide and Rodenticide Act (FIFRA), considering ice to be a "pest".

Biotechnica International nearly won approval for its field test of a recombinant strain of Rhizobium mililoti containing genes for nitrogen fixation under TSCA this summer. But snags developed in Biotechnica's antibiotic tracking system, because the marker they intended to use was also found widely in natural bacteria. Biotechnica is now working on a new set of antibiotic markers, and expects to begin its field test in Pepin County, Wisconsin on alfalfa plants in the spring of new year.

The Monsanto field test is scheduled to begin in November, in Blackville, South Carolina.

Carol Ezzell

\title{
Soviet-Chinese collaboration on the Silk Road
}

\section{London}

The Marco Polo expedition, which set out Silk Road from the Mediterranean to Beijing, proved a remarkable tribute to the current Soviet policy of glasnost and its Chinese equivalent. The five-man expedition, headed by historian Richard Fisher, hoped to be the first party to cover the entire route since the Portuguese monk de Goes in 1604 . Whether they technically achieved this goal is uncertain - neither they nor their vehicle crossed the IranianSoviet frontier at the planned place.

In spite of the expedition having all necessary clearances from Tehran, the fronier guards refused to allow it to cross the 'closed' frontier, and eventually the in May to travel the entire length of the

expedition had to return to Turkey and enter the Soviet Union from there.

The team planned to investigate the ethnology and culture of the peoples living along the route, taking holograms in situ of cultural and archaeological relics and to study the siting of the traditional caravanserais, to investigate how far this was conditioned by cultural and how far by purely practical considerations. Dr Charles O'Neill of the Imperial Cancer Research Fund has suggested that silica fibres from wild grasses in flour along the Silk Road might be the reason for the high incidence of oesophageal cancer in those regions, and the team's programme called for the collection of flour samples from bakeries, grasses and epidemiological and post

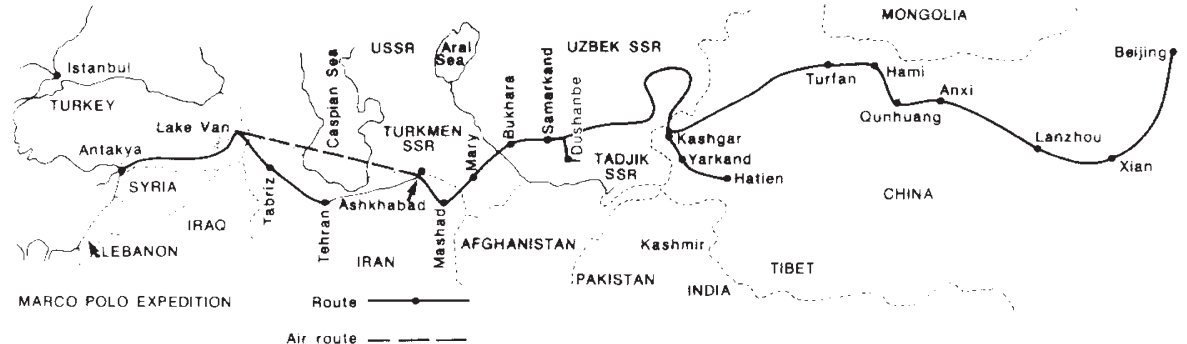

The 'Silk Road' - last travelled in its entirety in 1604 by a Portuguese monk.
MIT needs millions Washington

WinNing a Nobel prize clearly has its obligations. This week, the Massachusetts Institute of Technology (MIT) put its newest laureates, Susumu Tonegawa, who won the prize for medicine on October 12 , and David Saxon, who won the prize for economics on October 21 , on stage to launch an appeal for five hundred and fifty million dollars needed to ensure that MIT will continue as a world-beating institute.

The appeal, second in scale only to Stanford University's drive to raise a thousand million dollars, is the largest in MIT's history. A new science complex, to include a new biology building and remodelled facilities for the physics department - disciplines in which five of MIT's eight Nobel laureates work - is a major goal of the campaign. The new buildings and additional resources will allow a number of new research initiatives.

A nucleus fund of $\mathbf{2 1 0}$ million dollars has already been raised but finding the remainder in a five-year drive is not going to be easy with stiff competition expected from other universities seeking to renew outdated facilities. The funds should help MIT avoid too much reliance on shortterm government research support which Professor John Deutch, MIT's chief academic officer, says "threatens to limit the range and character of the scholarly enquiry we are able to undertake".

Alun Anderson

mortem data from the public health authorities. How far O'Neill's thesis could be tested today, when much Soviet wheat is pooled and consumed far from the site of origin is open to question. What is perhaps more significant is that, although some plant and flour specimens were collected, neither in the Soviet Union or in China were the public health authorities or the medical academies in touch with the expedition at all. Contacts arranged through the Royal Society were with the Academy of Sciences of the USSR and the Academia Scientia Sinica, which delegated liaison and cooperation to, respectively, their Institute of Geography and Institute of Geology. If multidisciplinary expeditions of this kind are to become more common in the formerly closed areas of Central Asia, the Soviet and Chinese hosts may find themselves expected to provide multidisciplinary assistance. This idea should appeal to $\mathrm{Mr}$ Gorbachev at least, since a main point of his restructuring programme for science is the elimination of inter-departmental boundaries. So far he has not attacked inter-Academy boundaries. The experience of the Marco Polo expedition suggests that this, too, may be necessary.

Vera Rich 